\title{
Selective Transport of Silver(I) Cation Across a Bulk Liquid Membrane Containing Bis- $\beta$-enamino Ester as Ion Carrier
}

\author{
Somayeh Tarahomi, Gholam Hossein Rounaghi, * Hossein Eshghi, leili Daneshvar and \\ Mahmoud Chamsaz
}

\author{
Department of Chemistry, Faculty of Science, Ferdowsi University of Mashhad, Mashhad, Iran
}

\begin{abstract}
Facilitated transport of silver(I) cation across a bulk liquid membrane by two synthesized ligands, bis- $\beta$-enamino ester (BBEE) and bis(benzoic acid) trioxaheptane (BBAT), as carriers dissolved in dichloromethane has been investigated. BBEE was used as a specific ion carrier for the transport of silver(I) ion. The influence of experimental parameters affecting the transport efficiency of silver(I) ion have been studied. In the presence of thiosulfate as a suitable metal ion acceptor in the receiving phase and picrate ion as ion pairing agent in the source phase, the amount of silver(I) ion transported across the liquid membrane after $120 \mathrm{~min}$ was found to be $97 \%$. Tolerance to the presence of different ions was investigated and it was found that silver(I) cation transport was not affected even in the presence of 10 -fold concentration of these metal cations in solution. This system was applied for the recovery of silver(I) cation from silver plating and photographic waste solution.
\end{abstract}

Keywords: facilitated transport, silver(I), bulk liquid membrane

\section{Introduction}

Silver is an important element that is mainly used in photographic and imaging industry, dental and medical products, electrical and electronic equipment and other products like jewelry, coins, and mirrors..$^{1-4}$ It is an important ion in some drugs like silver sulfadiazine cream that has been a standard treatment for burns over the past decades and silver deposition has been found in the skin, gingiva, cornea, liver, and kidney of patients. ${ }^{5,6}$ It is reported that the concentration of silver(I) cation in water higher than $0.17 \mu \mathrm{g} \mathrm{L}^{-1}$ is toxic to fish and microorganisms. It has also been found that silver is toxic to humans at a concentration as high as $97.2 \mu \mathrm{g} \mathrm{L}^{-1}$ in drinking water. ${ }^{7-10}$ On the other hand, owing to the fact that $\mathrm{Ag}^{+}$has moderate coordination ability, it is quite difficult to be discriminated from other chemically similar toxic elements. Therefore, separation and recovery of silver from waste and industrial sources are environmentally and economic important.

The solvent extraction process has already been industrially applied to the recovery of precious metal ions. ${ }^{11,12}$ However, the extraction rate of precious metals is understood to be kinetically very slow, and as a result a

*e-mail: ronaghi@um.ac.ir, ghrounaghi@yahoo.com huge amount of extractant and interfacial area are required to operate the process efficiently.

Compared with solvent extraction, liquid membranes have shown great potential since they combine the process of extraction and stripping in a single unit operation ${ }^{13,14}$ especially in the case where the solute concentration is relatively low and other techniques cannot be applied efficiently. The extraction chemistry of liquid membrane is similar to that found in classical liquid-liquid extraction, but the transport process is governed by kinetic rather than equilibrium parameters, under non-equilibrium mass transfer. ${ }^{15}$ Bulk liquid membrane (BLM) is one of the simplest designs for performing liquid membrane processes, which are often used to investigate the complexation and transport properties of synthetic and natural ionophores with metal salts. ${ }^{16-18}$

The carrier in the liquid membrane phase plays an important role in the liquid membrane process, which must: (i) provide a very high extraction distribution coefficient from dilute solutions; (ii) react reversibly with the metal so that the metal can be recovered by a stripping reaction; (iii) have reasonably fast extraction and stripping kinetic; and (iv) have very low solubility in the aqueous phase for economic and environmental reasons. ${ }^{19}$ There has been a number of papers dealing with $\mathrm{Ag}^{+}$transport through different liquid membrane configurations using various 
kinds of carriers. The choosing of the type of carrier is important in the design of metal separation.

In a study by Altin et $a l .^{20}$ transport of $\mathrm{Ag}^{+}$ion was investigated in $\mathrm{HNO}_{3}$ solution through a flat-sheet supported liquid membrane (SLM) process containing the membrane liquid prepared from a mixture of DC18C6 and toluene. Under optimum conditions, 94\% of $\mathrm{Ag}^{+}$ ions are carried from the feeding phase to the receiving phase. Amiri et al. ${ }^{21}$ have investigated selective transport of silver ion through supported liquid membrane using calix (4) pyrroles as a suitable ion carrier. Furthermore, it has been reported that various parameters such as carrier concentration in the membrane phase, thiosulfate concentration in strip phase, picric acid concentration in the feed phase, stirring speed and the type of solvent affect the transport of silver ion.

Also López-López et al. ${ }^{22}$ used tri-isobutylphosphine sulfide (TIBPS) as a carrier for the determination of total silver ion concentration in freshwaters by a bulk liquid membrane (BLM) system. High and selective $\mathrm{Ag}^{+}$bulk liquid membrane transport with $N, N$-diethyl- $N$ '-camphanyl thiourea as a carrier has been studied by Berhe et al. ${ }^{23}$ Vajda et $a l .{ }^{24}$ used Cyanex471X as a carrier in a bulk liquid membrane system. They observed that silver(I) ion transport increases as the $\mathrm{HNO}_{3}$ concentration in the aqueous phase and the carrier concentration in the solvent increases. In our previous works, we have transported efficiently the silver ion through bulk liquid membranes using different acyclic and cyclic ligands as carriers. ${ }^{25,26}$

In the present paper, we report the results of a selective and efficient bulk liquid membrane system containing bis- $\beta$-enamino ester (BBEE) as a synthesized carrier for transport of silver(I) ion. The parameters influencing the efficiency of the transport are verified. The selectivity of the method was checked by performing the competitive transport experiments of silver ions from its mixtures with some suspected interfering ions. The applicability of the proposed method was tested for recovering of silver ions in plating and photographic waste solution.

\section{Experimental}

\section{Reagents}

The carriers BBEE and bis(benzoic acid) trioxaheptane (BBAT) were synthesized by H. Eshghi research Group (Department of Chemistry, Ferdowsi University of Mashhad). Reagent grade dichloromethane (Aldrich), 1,2-dichloroethane (Merck) and chloroform (Merck) were tested as organic phases. Analytical grade silver nitrate (Merck), sodium thiosulfate (Merck) and all other chemicals were of the highest purity available and used without further purification. Doubly distilled deionized water was used throughout all experiments.

\section{Apparatus}

The determination of silver(I) content was carried out by a Shimadzu AA-670 atomic absorption spectrometer equipped with an Ag-hallow cathode lamp (HCL) and was made under the recommended conditions for silver cation. The $\mathrm{pH}$ measurements were accomplished with a Metrohm model $692 \mathrm{pH} /$ ion meter equipped with a combined glass- $\mathrm{Ag} / \mathrm{AgCl}$ electrode. The membrane phase was stirred including a Teflon-coated magnetic bar by magnetic stirrer (Daihan MSH-20D). A bulk type liquid membrane cell was used in all transport experiments.

\section{Procedure}

A glass cylindrical cell (internal diameter-i.d. $5.0 \mathrm{~cm}$ ) holding a glass tube (i.d. $2.0 \mathrm{~cm}$ ) which separates the source and receiving aqueous phases was used for the transport experiments (Scheme 1). The source (feed) phase consisted of $10 \mathrm{~mL}$ of buffer solution at $\mathrm{pH} 5.0 \pm 0.1$ containing silver nitrate $\left(5 \times 10^{-5} \mathrm{~mol} \mathrm{~L}^{-1}\right)$.

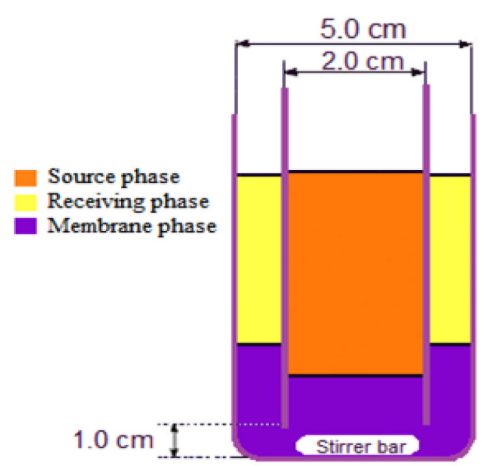

Scheme 1. Experimental set-up for the transport experiments.

The receiving (strip) phase included $30 \mathrm{~mL}$ of buffer solution at $\mathrm{pH} 5.0 \pm 0.1$ containing sodium thiosulfate solution $\left(0.02 \mathrm{~mol} \mathrm{~L}^{-1}\right)$. A dichloromethane layer $(50 \mathrm{~mL})$ containing $8 \times 10^{-4}$ mol L-1 of the ligand lay below these two aqueous phases and bridged them. The $\mathrm{pH}$ of each source and receiving phases were adjusted using $\mathrm{CH}_{3} \mathrm{COOH} / \mathrm{CH}_{3} \mathrm{COONa}$ buffer solution. The cells were covered with cover slips in order to prevent evaporation of solvents and then entirely covered by aluminum foil in order to prevent the light-induced reduction of $\mathrm{Ag}^{+}$in the source phase.

All transport experiments were carried out at ambient temperature. The organic phase was magnetically stirred 


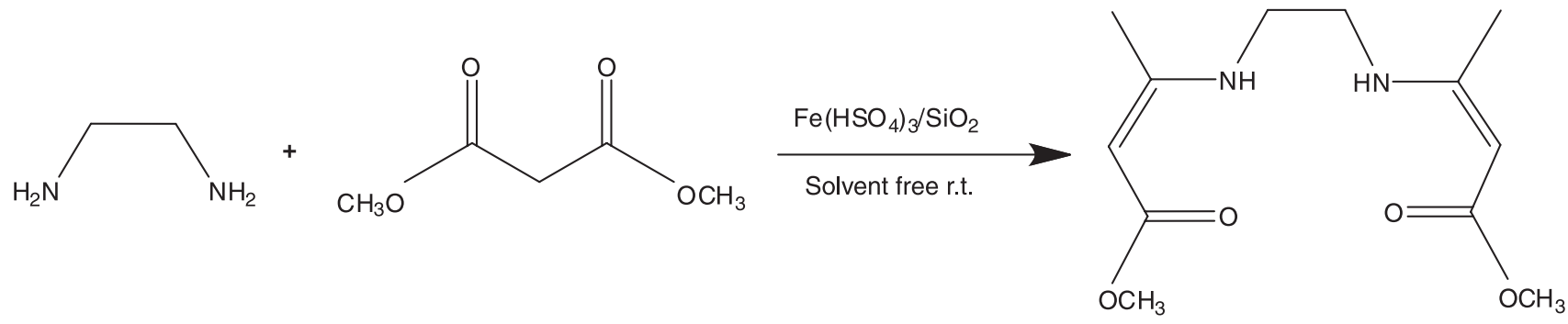

$\mathrm{L}_{1}$
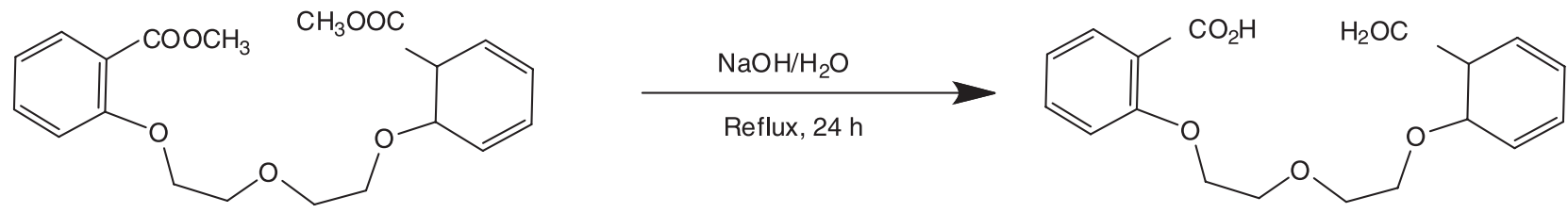

$\mathbf{L}_{2}$

Scheme 2. Synthetic pathway for the preparation of BBEE $\left(\mathrm{L}_{1}\right)$ and $\operatorname{BBAT}\left(\mathrm{L}_{2}\right)$.

by a Teflon-coated magnetic bar at $300 \mathrm{rpm}$. All transport runs were terminated after $120 \mathrm{~min}$ and samples of both aqueous phases were analyzed for metal content by atomic absorption spectroscopy. The reproducibility was performed under optimized conditions and the transport process was investigated by performing five replicate transport experiments. The relative standard deviation was found to be $1.5 \%$.

\section{Synthesis}

The synthesis of BBEE and BBAT ligands is depicted in Scheme 2. These carriers were prepared according to the literature methods..$^{27,28}$

\section{Synthesis of bis- $\beta$-enamino ester (BBEE)}

A mixture of the dimethyl malonate $(4 \mathrm{mmol})$, ethylene diamine $(2 \mathrm{mmol})$ and $\mathrm{Fe}\left(\mathrm{HSO}_{4}\right)_{3} \cdot \mathrm{SiO}_{2}(0.22 \mathrm{~g}$ containing $0.25 \mathrm{mmol}$ of $\left.\mathrm{Fe}\left(\mathrm{HSO}_{4}\right)_{3}\right)$ was stirred in solvent-free conditions at room temperature for $10 \mathrm{~min}$. After completing the reaction as indicated by thin layer chromatography (TLC), the mixture was diluted by ethyl acetate $(15 \mathrm{~mL})$. The insoluble catalyst was separated by filtration and rinsed with ethyl acetate and dried. The solvent was evaporated from the filtrate and the crude product was purified by recrystallization from $\mathrm{EtOH} / \mathrm{H}_{2} \mathrm{O}$ (1:1). Yield: $98 \%$; mp 137-139 ${ }^{\circ} \mathrm{C}$; IR (KBr) $\mathrm{v} / \mathrm{cm}^{-1} 3308,2957,1656,1582,1279,1171 ;{ }^{1} \mathrm{H}$ NMR $\left(100 \mathrm{MHz} \mathrm{CDCl}_{3}\right) \delta 8.6(\mathrm{~b}, 2 \mathrm{H}), 4.5(\mathrm{~s}, 2 \mathrm{H}), 3.6(\mathrm{~s}, 6 \mathrm{H})$, $3.35(\mathrm{~m}, 4 \mathrm{H}), 1.9(\mathrm{~s}, 6 \mathrm{H})$.
Synthesis of 1,7-bis(2'-benzoic acid)-1,4,7-trioxaheptane (BBAT)

A solution of 1,7-bis(2'-methyl benzoate)-1,4,7trioxabeptane $(37.5 \mathrm{~g}, 0.1 \mathrm{~mol})$ in $10 \%$ aqueous $\mathrm{NaOH}$ $(500 \mathrm{~mL})$ was refluxed for $24 \mathrm{~h}$. The mixture was cooled and washed with chloroform $(2 \times 100 \mathrm{~mL})$ and acidified with $\mathrm{HCl}\left(6 \mathrm{~mol} \mathrm{~L}^{-1}\right)$ and extracted with $\mathrm{CH}_{2} \mathrm{Cl}_{2}(5 \times 150 \mathrm{~mL})$. The solvent was evaporated and the white solid was recrystallized from $\mathrm{CH}_{2} \mathrm{Cl}_{2}$ to give white crystal of BBAT. Yield: $34.5 \mathrm{~g}(100 \%)$; $\mathrm{mp} 105{ }^{\circ} \mathrm{C}$; IR (KBr) v / cm ${ }^{-1} 1700$; ${ }^{1} \mathrm{H}$ NMR (100 MHz, CDC1 $\left.1_{3}\right), \delta 3.85$ (t, 4H, J 4.5 Hz), $4.20(\mathrm{t}, 4 \mathrm{H}, J 4.5 \mathrm{~Hz}), 6.8-7.1(\mathrm{~m}, 4 \mathrm{H}), 7.35$ (dt, 2H, $J_{1} 8$, $\left.J_{2} 2 \mathrm{~Hz}\right), 7.9\left(\mathrm{dd}, 2 \mathrm{H}, J_{1} 8, J_{2} 2 \mathrm{~Hz}\right), 8.3$ (b, 2H).

\section{Results and Discussion}

The liquid membrane technique is composed of two processes in a single stage: extraction of an ion from aqueous feed (donor) solution to organic phase containing the carrier molecules (membrane) and back extraction of this ion from the membrane to aqueous strip (acceptor) phase. The overall transport process consists of a diffusion step and a complexation/decomplexation reaction at two independent and different interfaces. The membrane studies were carried out because simple and energy efficient systems are necessary in a practical application point of view.

Chelating agents containing sulfur or nitrogen atoms as coordination sites possess great affinity toward $\mathrm{d} 10$ transition metal ions like $\mathrm{Ag}^{+}$. Thus, the formation of 
complex with metal cations may be primarily attributed to the affinity of the metal ion for nitrogen atoms. ${ }^{29,30} \mathrm{Of}$ course, the relative size of the metal ion and cavity of the ligand can also play an important role in the selectivity of the resulting complex.

In preliminary experiments, BBEE and BBAT ligands were tested as silver ion carriers. Among these ligands examined, BBEE was used as a carrier for the selective and efficient transport of $\mathrm{Ag}^{+}$across a bulk liquid membrane. Meanwhile, the experimental variables were optimized in order to achieve the highest efficiency in the transport of silver(I) cation.

Nezhadali et al. ${ }^{31}$ applied a bulk liquid membrane for selective separation of $\mathrm{Ag}^{+}$cation using 1,1'-(1,3-phenylene) bis(3-allylthiourea) as a carrier and their results, showed that the transport efficiency of this metal cation for the five replicate measurements after $4 \mathrm{~h}$, was $92.3 \pm 5.3 \%$. The results obtained in our experiments, show a better efficiency and precision for selective transport of $\mathrm{Ag}^{+}$ion through bulk liquid membrane using bis- $\beta$-enamino ester (BBEE) ligand. To our knowledge, the transport of silver(I) cation across the bulk liquid membranes using this synthesized ligand, has not been reported.

\section{Effect of the nature of the carrier and its concentration}

The permeability of the membrane system used for transport of $\mathrm{Ag}^{+}$ion also depends largely on the nature of ligand used as carrier in the organic membrane phase. As it is seen from Table 1, under similar experimental conditions, the efficiency of silver ion transport decreases in the order $\mathrm{L}_{1}>\mathrm{L}_{2}$. This is presumably related to the increased stability of the $\mathrm{AgL}_{1}{ }^{+}$complex in comparison with the corresponding complex with $\mathrm{L}_{2}$ ligand, the observed trend may also be originated from the suitable lipophilic-hydrophobic balance and flexibility which allow sufficiently fast exchange rates of $\mathrm{AgL}_{1}{ }^{+}$for loading and unloading in order to avoid carrier saturation.

In order to investigate the effect of the concentration of $\mathrm{L}_{1}$ on the transport of silver(I) ion, the experiments

Table 1. Effect of carrier structure on silver(I) transport ${ }^{\mathrm{a}}$

\begin{tabular}{lcc}
\hline Carrier & $\begin{array}{c}\text { Percentage transported } \\
\text { into strip phase }\end{array}$ & $\begin{array}{c}\text { Percentage remaining } \\
\text { into feed phase }\end{array}$ \\
\hline BBEE & 97 & 2 \\
BBAT & 25 & 60 \\
\hline
\end{tabular}

aConditions: feed phase, $10 \mathrm{~mL}$ of $5 \times 10^{-5} \mathrm{~mol} \mathrm{~L}^{-1} \mathrm{Ag}^{+}, 6.0 \times 10^{-3} \mathrm{~mol} \mathrm{~L}^{-1}$ of picric acid; membrane phase, $8.0 \times 10^{-4} \mathrm{~mol} \mathrm{~L}^{-1}$ carriers in DCM; strip phase, $30 \mathrm{~mL}$ of $0.02 \mathrm{~mol} \mathrm{~L}^{-1}$ sodium thiosulfate; time of transport, $120 \mathrm{~min}$; stirring speed, $300 \mathrm{rpm}$; BBEE: bis- $\beta$-enamino ester; BBAT: bis(benzoic acid) trioxaheptane. were run at different carrier concentrations and the transport procedure was followed. As it is seen from Figure 1, silver(I) ion transport increases with increasing the concentration of $\mathrm{L}_{1}$ in the membrane phase up to an $8.0 \times 10^{-4} \mathrm{~mol} \mathrm{~L}^{-1}$ level. While a further increase in the carrier concentration not only has no improved effect on the percentage of transported silver ion, but also results in a slight decrease in extraction efficiency. As is evident in Table 1 and Figure 2, in the optimized concentration of the ligand, the transport efficiency of $\mathrm{Ag}^{+}$cation through DCM liquid membrane is about $97 \%$.

A similar behavior for the carrier concentration in the LM has already been reported in the literature. ${ }^{32}$ This could be due to the more difficult release of the cation into the receiving solution, as a result of its firm bounding to the carrier, and/or the increased viscosity of the membrane with increasing carrier concentration.

In addition, a blank experiment was performed in which the membrane contained no carrier. No detectable transport of the silver(I) ions through the liquid membrane was found in the blank experiment, suggesting that the transport of the silver ions through the liquid membrane was fulfilled by the carrier. Therefore, the carrier is essential to transport the silver(I) ions from the feed phase.

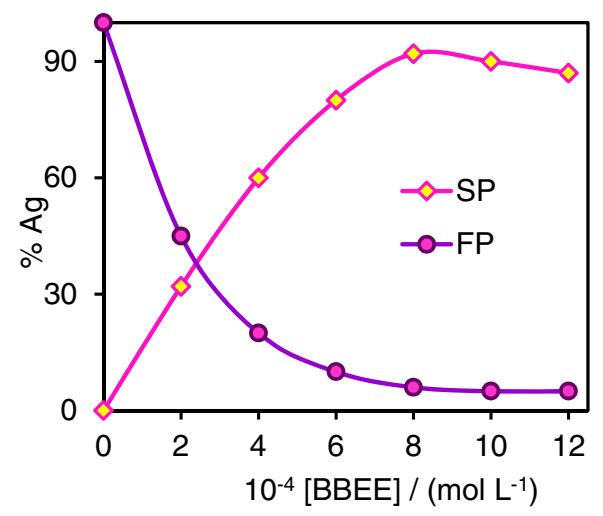

Figure 1. Effect of carrier $\left(\mathrm{L}_{1}\right)$ concentration in the membrane phase on silver ion transport. Conditions: feed phase, $10 \mathrm{~mL}$ of $5 \times 10^{-5} \mathrm{~mol} \mathrm{~L}^{-1} \mathrm{Ag}^{+}$, $6.0 \times 10^{-3} \mathrm{~mol} \mathrm{~L}^{-1}$ of picric acid; membrane phase, varying concentrations of $\mathrm{L}_{1}$ in DCM; strip phase, $30 \mathrm{~mL}$ of $0.02 \mathrm{~mol} \mathrm{~L}^{-1}$ sodium thiosulfate; time of transport, $120 \mathrm{~min}$; stirring speed, $300 \mathrm{rpm}$.

\section{Effect of picric acid concentration in the feed phase}

In preliminary experiments, it was found that nitrate ion is not a suitable counter ion to accompany the $\mathrm{AgL}_{1}{ }^{+}$ complex into the membrane phase, and the transport of silver ion through the BLM used was found to be negligible. However, addition of picric acid to the feed solution resulted in a further increase in transport efficiency so that $>90 \%$ silver transport was obtained after $120 \mathrm{~min}$. It is well known that the soft, polarizable and weakly hydrated 
picrate ion is a convenient counter ion that provides greater distribution ratios and membrane transport rates for metal ion-neutral ligand complexes than do inorganic ions such as $\mathrm{NO}_{3}{ }^{-}$and $\mathrm{ClO}_{4}^{-} \cdot{ }^{-33}$

For this reason, picrate ion was selected as a suitable counter ion. Then, the influence of the picric acid concentration in the feed phase on the silver ion transport was studied. It was found that, the efficiency of silver ion transport increases with increasing picric acid concentration up to $6.0 \times 10^{-3} \mathrm{~mol} \mathrm{~L}^{-1}$ concentration is reached. However, a further increase in the concentration of picric acid caused a decrease in the percentage transport of silver ion, most possibly due to the fact that the picric acid itself competes with silver nitrate for transport through the BLM system.

\section{Effect of organic solvent in the membrane phase}

In order to study the influence of the organic solvent on transport efficiency, dichloromethane (DCM), 1,2-dichloroethane (DCE) and chloroform $\left(\mathrm{CHCl}_{3}\right)$ were used as organic membranes. From the results which are summarized in Table 2, it can be seen that the order of the amount of the $\mathrm{Ag}^{+}$released into the receiving phase varies as: $\mathrm{CHCl}_{3}<\mathrm{DCE}<\mathrm{DCM}$. The highest transport efficiency was obtained in the case of DCM. Chloroform was found to be an unsuitable solvent for the transport of $\mathrm{Ag}^{+}$cation. Considering the polarity of the organic solvents, one can attribute that the viscosity and polarity are essential factors for solvent selection for BLM phenomena. This is consistent with the literature reported. ${ }^{34}$

Table 2. Effect of organic solvent on silver(I) transport $^{\mathrm{a}}$

\begin{tabular}{lcc}
\hline Solvent & $\begin{array}{c}\text { Percentage transported } \\
\text { into strip phase }\end{array}$ & $\begin{array}{c}\text { Percentage remaining } \\
\text { into feed phase }\end{array}$ \\
\hline Dichloromethane & 95 & 3 \\
Dichloroethane & 69 & 23 \\
Chloroform & 20 & 71 \\
\hline
\end{tabular}

aConditions similar to those mentioned in Table 1, except for solvent type.

\section{Effect of stripping agent in receiving phase}

The strength of the acceptor phase (strip phase) for the transport of $\mathrm{Ag}^{+}$ion is significant on both efficiency and selectivity of the transport. If the metal ion-complex is not completely stripped into the receiving phase, the membrane phase becomes saturated with the complex and, therefore, the transport rate will decrease. ${ }^{35}$

The percentages of silver ion transport in the presence of different stripping agents such as $\mathrm{SCN}^{-}, \mathrm{S}_{2} \mathrm{O}_{3}{ }^{2-}, \mathrm{CN}^{-}$, thiourea, ethylenediamine tetraacetic acid (EDTA) and
$\mathrm{P}_{2} \mathrm{O}_{7}{ }^{2-}$, were determined under similar experimental conditions.

The results showed that among the studied stripping agents, the presence of thiosulfate $\left(\mathrm{S}_{2} \mathrm{O}_{3}\right)^{2-}$ in the receiving phase showed the highest transport efficiency for silver(I) cation.

In some cases, the total percentage of the silver ion in the feed and strip phases is not equal to 100 , due to the fact that some reasonable amount of the silver(I) cation is remained in the membrane phase, especially when the stripping agent does not have high enough tendency to completely release the silver ion from the $\left(\mathrm{AgL}_{1}{ }^{+}\right) \mathrm{Pic}^{-}$ adduct from the membrane phase into the receiving phase.

The optimum concentration of sodium thiosulfate in strip phase was investigated and it was found to be: $0.02 \mathrm{~mol} \mathrm{~L}^{-1}$ (Figure 2). It should be noted that, in the absence of $\mathrm{S}_{2} \mathrm{O}_{3}{ }^{2-}$ ion in the strip phase, no measurable transport occurred in a time period of $120 \mathrm{~min}$. However, the transport process of the $\mathrm{Ag}^{+}$ion through the membrane phase decreases at lower or higher concentrations of $\mathrm{Na}_{2} \mathrm{~S}_{2} \mathrm{O}_{3}$. In the studies by Nowier et al..$^{36}$ and Altin et al. ${ }^{20}$ it was reported that increasing stripping phase concentration facilitates achieving an optimum permeability value. The reason for this may be explained as the concentration of the solute increases, the solution reaches saturation value and, therefore, the solubility decreases. In this case, the amount of $\left(\mathrm{S}_{2} \mathrm{O}_{3}\right)^{2-}$ ions which would form a complex with the silver ions in the membrane/stripping interface decreases.

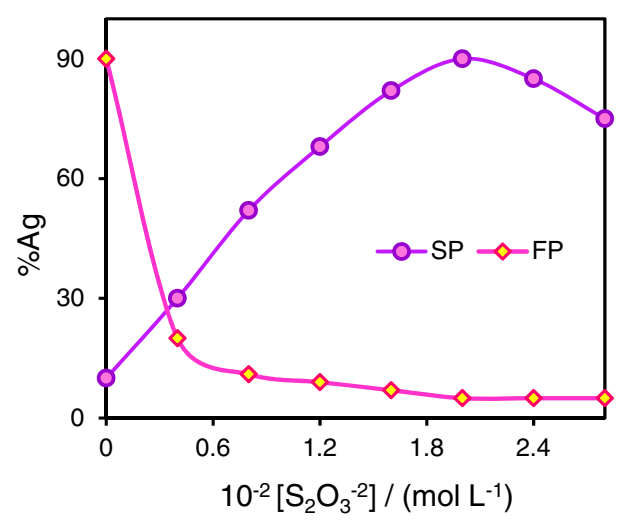

Figure 2. Effect of thiosulfate ion concentration in the strip phase on silver ion transport. Conditions: feed phase, $10 \mathrm{~mL}$ of $5.0 \times 10^{-5} \mathrm{~mol} \mathrm{~L}^{-1} \mathrm{Ag}^{+}$, $6.0 \times 10^{-3} \mathrm{~mol} \mathrm{~L}^{-1}$ of picric acid; membrane phase $8.0 \times 10^{-4} \mathrm{~mol} \mathrm{~L}^{-1} \mathrm{~L}_{1}$ in DCM; strip phase, $30 \mathrm{~mL}$ of varying concentration of sodium thiosulfate; time of transport, $120 \mathrm{~min}$; stirring speed, $300 \mathrm{rpm}$.

\section{Effect of $\mathrm{pH}$ of the feed and striping phases}

The influence of $\mathrm{pH}$ of the source and receiving phases on the transport efficiency of $\mathrm{Ag}^{+}$ion was studied in $\mathrm{pH}$ range 3-8 and it was found that maximum transport of this 
metal occurs at $\mathrm{pH}$ 5. This shows that the transport does not follow a proton driven mechanism. ${ }^{25}$

\section{Effect of the stirring speed}

In order to explore the effect of stirring speed on the $\mathrm{Ag}^{+}$transport, several transport experiments were performed with different stirring speeds (50-400 rpm) and the results indicate that the stirring speed affects the transport efficiency of $\mathrm{Ag}^{+}$ion through the organic membrane phase.

The percentage of transported $\mathrm{Ag}^{+}$ion increases up to about $300 \mathrm{rpm}$ and then decreases. However, further increase in the stirring rate results in some decrease in the transport efficiency of the metal cation owing to the high turbulence flow caused by stirring, which possibly causes the displacement of some carrier molecules from the membrane. Similar behavior has been observed by Muthuraman et al. ${ }^{37}$ at higher stirring speed.

Time dependency of the transport process

The experimental results obtained for investigate the effect of time on the transport efficiency show that the amount of $\mathrm{Ag}^{+}$ion extracted from the source phase into the receiving phase increases with time (Figure 3). It was found that, under the optimum experimental conditions, the transport of $\mathrm{Ag}^{+}$ion is almost quantitative after $120 \mathrm{~min}$.

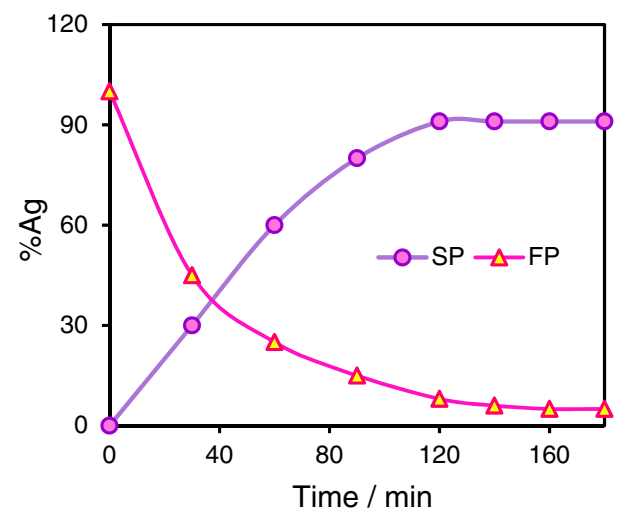

Figure 3. Time dependence of silver ion transport. Conditions: feed phase, $10 \mathrm{~mL}$ of $5.0 \times 10^{-5} \mathrm{~mol} \mathrm{~L}^{-1} \mathrm{Ag}^{+}, 6.0 \times 10^{-3} \mathrm{~mol} \mathrm{~L}^{-1}$ of picric acid; membrane phase, $8.0 \times 10^{-4} \mathrm{~mol} \mathrm{~L}^{-1} \mathrm{~L}_{1}$ in DCM; strip phase, $30 \mathrm{~mL}$ of $0.015 \mathrm{~mol} \mathrm{~L}^{-1}$ sodium thiosulfate; varying time of transport; stirring speed, $300 \mathrm{rpm}$.

\section{Reproducibility of the liquid membrane system}

Under optimum conditions, the reproducibility of the method was investigated and the percent of the silver(I) ion transported after $120 \mathrm{~min}$ from 5 replicate measurements was found to be $97 \%$ with a standard deviation of $\pm 1.5 \%$.

\section{Selectivity of bulk liquid membrane system}

The selectivity of a BLM system is a parameter that allows the evaluation of the degree of purification of a target analyte with respect to the other species present in solutions. The selectivity of the process towards silver ion was tested by performing the transport of $\mathrm{Ni}^{2+}, \mathrm{Pb}^{2+}, \mathrm{Zn}^{2+}, \mathrm{Co}^{2+}, \mathrm{Cd}^{2+}$, $\mathrm{Cu}^{2+}, \mathrm{Cr}^{3+}, \mathrm{Mn}^{2+}, \mathrm{Al}^{3+}, \mathrm{Fe}^{2+}$ and $\mathrm{Fe}^{3+}$ metal cations containing $\mathrm{Ag}^{+}$ion in their mixtures. The results are summarized in Table 3. It was found that even in the presence of 10 -fold concentrations of these metal ions with respect to $\mathrm{Ag}^{+}$ion, there is no serious interference in the transport process of this heavy metal ion.

Table 3. Percentages of cation transported from various cation mixtures through the BLM system ${ }^{a}$

\begin{tabular}{|c|c|c|}
\hline Mixture of cations & $\begin{array}{l}\text { Percentage transported } \\
\text { into strip phase }\end{array}$ & $\begin{array}{c}\text { Percentage remaining } \\
\text { in feed phase }\end{array}$ \\
\hline \multicolumn{3}{|l|}{ Mixture 1} \\
\hline $\mathrm{Ag}^{+}$ & 93 & 5 \\
\hline $\mathrm{Cd}^{2+}$ & 3 & 95 \\
\hline $\mathrm{Zn}^{2+}$ & 4 & 82 \\
\hline \multicolumn{3}{|l|}{ Mixture 2} \\
\hline $\mathrm{Ag}^{+}$ & 93 & 4 \\
\hline $\mathrm{Pb}^{2+}$ & 7 & 87 \\
\hline $\mathrm{Fe}^{2+}$ & 0 & 99 \\
\hline $\mathrm{Cu}^{2+}$ & 5 & 92 \\
\hline \multicolumn{3}{|l|}{ Mixture 3} \\
\hline $\mathrm{Ag}^{+}$ & 94 & 3 \\
\hline $\mathrm{Co}^{2+}$ & 3 & 94 \\
\hline $\mathrm{Ni}^{2+}$ & 0 & 97 \\
\hline $\mathrm{Mn}^{2+}$ & 0 & 98 \\
\hline \multicolumn{3}{|l|}{ Mixture 4} \\
\hline $\mathrm{Ag}^{+}$ & 95 & 2 \\
\hline $\mathrm{Fe}^{3+}$ & 0 & 98 \\
\hline $\mathrm{Cr}^{3+}$ & 0 & 99 \\
\hline $\mathrm{Al}^{3+}$ & 0 & 98 \\
\hline \multicolumn{3}{|l|}{ Mixture 5} \\
\hline $\mathrm{Ag}^{+}$ & 95 & 2 \\
\hline $\mathrm{K}^{+}$ & 0 & 98 \\
\hline $\mathrm{Ca}^{2+}$ & 0 & 99 \\
\hline
\end{tabular}

${ }^{\mathrm{a} C o n d i t i o n s ~ s i m i l a r ~ t o ~ t h o s e ~ m e n t i o n e d ~ i n ~ T a b l e ~} 1$.

\section{Suggested mechanism}

The transport of silver ion by using the BBEE ligand, obeys a facilitated co-transport. As is shown in Figure 4, the silver ion forms a single charge complex at the interface between the source phase and membrane phase and after forming a hydrophobic ion pair with picrate ion, the resulting ion-paired complex diffuses through the complex 
with thiosulfate ion $\left(\mathrm{L}_{1}-\mathrm{Ag}\right.$-thiosulfate). Then the free carrier diffuses back across the liquid membrane and the cycle starts again. The net result is the transport of silver ion from the source phase to the receiving phase across the membrane.

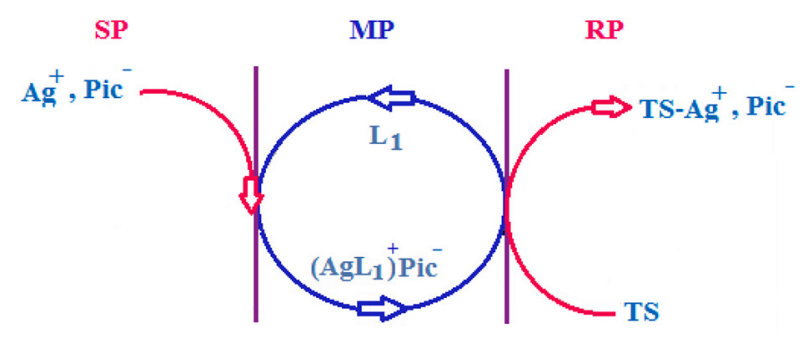

Figure 4. Simplified representation of the transport mechanism of silver ion by carrier $\left(\mathrm{L}_{1}\right)$. Source phase (SP), membrane phase (MP), receiving phase (RP).

Application of BLM for silver plating and photographic waste solution

The BLM system used for $\mathrm{Ag}^{+}$ion extraction has been applied for recovery of $\mathrm{Ag}^{+}$ions from silver plating and photographic waste solutions. The composition of silver plating and photographic waste solution is shown in Table 4. Under optimized experimental conditions, the $\mathrm{Ag}^{+}$ions were removed up to $95 \%$ in a time interval of $120 \mathrm{~min}$ and the results indicate that only the silver ion is transported which show that the selectivity and efficiency of this method are high for silver ion recovery in these real samples.

Table 4. Composition of silver plating and photographic waste solution

\begin{tabular}{lccc}
\hline Sample & $\begin{array}{c}\text { Metal } \\
\text { ion }\end{array}$ & $\begin{array}{c}\text { Concentration in } \\
\text { feed solution } \\
\left(\times 10^{-4} \mathrm{~mol} \mathrm{dm}^{-3}\right) / \\
\left(\mathrm{mol} \mathrm{L}^{-1}\right)\end{array}$ & $\begin{array}{c}\text { Concentration in } \\
\text { strip solution } \\
\left(\times 10^{-4} \mathrm{~mol} \mathrm{dm}^{-3}\right) / \\
\left(\mathrm{mol} \mathrm{L}^{-1}\right)\end{array}$ \\
\hline Silver plating & $\mathrm{Ag}$ & 5.75 & 5.50 \\
waste & $\mathrm{Cu}$ & 0 & 0 \\
& $\mathrm{Bi}$ & 0 & 0 \\
& $\mathrm{Cr}$ & 0 & 0 \\
Photographic & $\mathrm{Ag}$ & 4.12 & 0 \\
waste & $\mathrm{Fe}$ & 3.85 & 0 \\
& $\mathrm{Mg}$ & 1.51 & 0 \\
& $\mathrm{~K}$ & 23.2 & 0 \\
\hline
\end{tabular}

\section{Conclusions}

The quantitative transport of $\mathrm{Ag}^{+}$ion through a dichloromethane bulk liquid membrane containing bis- $\beta$ - enamino ester (BBEE) as a carrier was studied and it was found that this ligand is an excellent carrier for selective and efficient transport of silver(I) cation. The optimum conditions of the transport was found as $5.0 \times 10^{-5}$ and $6.0 \times 10^{-3} \mathrm{~mol} \mathrm{~L}^{-1}$ for $\mathrm{Ag}^{+}$and picric acid, respectively, in the source phase $(\mathrm{pH} 5), 8.0 \times 10^{-4} \mathrm{~mol} \mathrm{~L}^{-1} \mathrm{BBEE}$ in the dichloromethane membrane, $2.0 \times 10^{-2} \mathrm{~mol} \mathrm{~L}^{-1}$ thiosulfate in the receiving phase ( $\mathrm{pH} 5)$, stirring speed of $300 \mathrm{rpm}$ and a transport time period of $120 \mathrm{~min}$. The excellent efficiency and high degree of selectivity for the silver(I) cation transport by the proposed BLM system, reveals its potential application for the selective removal, concentration and purification of silver ion from its different mixtures. Up to $95 \%$ of $\mathrm{Ag}^{+}$ion has been removed from silver plating and photographic waste solutions, which indicates that this technique can be used for recovery of $\mathrm{Ag}^{+}$ion from industrial wastes effluents. This method offers important advantages such as simplicity, low cost and high selectivity.

\section{Acknowledgments}

Financial supports from the Ferdowsi University of Mashhad (grant No. 20192.3) are gratefully acknowledged.

\section{References}

1. Wang, X.; Zhang, L.; Ma, C.; Song, R.; Hou, H.; Li, D.; Hydrometallurgy 2009, 100, 82.

2. Song, S.; Ji, C.; Wang, M.; Wang, C.; Sun, C.; Qu, R.; Wang, C.; Chen, H.; J. Chem. Eng. Data 2011, 56, 1001.

3. Rehman, S.; Akhtar, G.; Chaudry, M. A.; Ali, K.; Ullah, N.; J. Membr. Sci. 2012, 389, 287.

4. White, R. J.; Br. J. Nurs. 2001, 10, S3.

5. Abu-Shawish, H. M.; Saadeh, S. M.; Dalloul, H. M.; Najri, B.; Al Athamna, H.; Sens. Actuators, B 2013, 182, 374.

6. Matsuda, K.; Hiratsuka, N.; Koyama, T.; Kurihara, Y.; Hotta, O.; Itoh, Y.; Shiba, K.; Clin. Chem. 2001, 47, 763.

7. Zhang, T.; Chai, Y.; Yuan, R.; Guo, J.; Mater. Sci. Eng., C 2012 , $32,1179$.

8. Lai, C.-Z.; Fierke, M. A.; Costa, R. C.; Gladysz, J. A.; Stein, A.; Buhlmann, P.; Anal. Chem. 2010, 82, 7634.

9. Wygladacz, K.; Radu, A.; Xu, C.; Qin, Y.; Bakker, E.; Anal. Chem. 2005, 77, 4706.

10. Environmental Protection Agency (EPA); EPA 7440-7422-7444, Office of Water Regulations: Washington, DC, 1989.

11. Akin, I.; Erdemir, S.; Yilmaz, M.; Ersoz, M.; J. Hazard. Mater. 2012, 223, 24.

12. López-López, J. A.; García-Vargas, M.; Moreno, C.; Talanta 2013, 108, 7 .

13. Shamsipura, M.; Davarkhah, R.; Khanchi, A. R.; Sep. Purif. Technol. 2010, 71, 63. 
14. Alizadeh, T.; Memarbashi, N.; Sep. Purif. Technol. 2012, 90 , 83.

15. Yang, X. J.; Fane, A. G.; Sep. Sci. Technol. 1999, 34, 1873.

16. Singh, N.; Jang. D. O.; Supramol. Chem. 2009, 21, 351.

17. Dalali, N.; Yavarizadeh, H.; Agrawal, Y. K. J.; Ind. Eng. Chem. 2012, 18, 1001.

18. Revathi Reddy, T.; Ramkumar, J.; Chandramouleeswaran, S.; Reddy, A. V. R.; J. Membr. Sci. 2010, 351, 11.

19. Raghuraman, B. J.; Tirmizi, N.; Wiencek, J.; Environ. Sci. Technol. 1994, 28, 1090.

20. Altin, S.; Yildirim, Y.; Altin, A.; Hydrometallurgy 2010, 103, 144.

21. Amiri, A. A.; Safavi, A.; Hasaninejad, A. R.; Shrghi, H.; Shamsipur, M.; J. Membr. Sci. 2008, 325, 295.

22. López-López, J. A.; García-Vargas, M.; Moreno, C.; Int. J. Environ. Anal. Chem. 2012, 92, 636.

23. Berhe, H. G.; Bourne, S. A.; Bredenkamp, M. W.; Esterhuysen, C.; Habtu, M. M.; Koch, K. R.; Luckay, R. C.; Inorg. Chem. Commun. 2006, 9, 99.

24. Vajda, M.; Schlosser, S.; Kovacova, K.; Chem. Pap. 2000, 54, 423.

25. Rounaghi, G. H.; Kazemi, M. S.; Sadeghian, H.; J. Inclusion Phenom. Macrocyclic Chem. 2008, 60, 79.

26. Rounaghi, G. H.; Kazemi, M. S.; J. Inclusion Phenom. Macrocyclic Chem. 2006, 55, 347.
27. Sharghi, H.; Eshghi, H.; Tetrahedron 1995, 51, 913.

28. Eshghi, H.; Safaei, E.; Seyedi, S. M.; Eshghi, T.; C. R. Chim. 2014, 17, 1088.

29. Campazzi, E.; Solari, E.; Scopelliti, R.; Floriani, C.; Chem. Commun. 1999, 1617.

30. Campazzi, E.; Solari, E.; Floriani, C.; Scopelliti, R.; Chem. Commun. 1998, 2603.

31. Nezhadali, A.; Es'haghi, Z.; Bahar, S.; Banaeia, A.; Shiran, J. A.; J. Braz. Chem. Soc. 2016, 27, 99.

32. Parthasarathy, N.; Buffle, J.; Anal. Chim. Acta 1991, 254, 9.

33. Talanova, G. G.; Elkarim, N. S. A.; Talanov, V. S.; Hanes, R. E.; Hwang, H. S. Bartsch, R. A.; Rogers, R. D.; J. Am. Chem. Soc. 1999, 121, 11281.

34. Ersoz, M.; Adv. Colloid Interface Sci. 2007, 134-135, 96.

35. Ren, Z. Q.; Zhang, W. D.; Liu, Y. M.; Dai, Y.; Cui, C. H.; Chem. Eng. Sci. 2007, 62, 6090.

36. Nowier, H. G.; El-Said, N.; Aly, H. F.; J. Membr. Sci. 2000 , 177,41 .

37. Muthuraman, G.; Teng, T. T.; Leh, C. P.; Norli, I.; Desalination 2009, 249, 884.

Submitted: February 26, 2016

Published online: May 10, 2016 